\title{
高齢者の後方歩行の特徵およびバランス能力との 関連性
}

\author{
Relationship between the Characteristics of Elderly Person's Backward \\ Walking and Balance
}

\author{
美和香葉子 1) 大杉 紘徳 $^{1)}$ 重森 健太 ${ }^{2)}$ 吉川 卓司 ${ }^{2)}$ \\ KAYOKO MIWA $^{1)}$, Hironori OSUGI ${ }^{1)}$, KENTA SHIGEMORI ${ }^{2)}$, TAKASHI YOSHIKAWA ${ }^{2)}$ \\ 1) Undergraduate Student, Seirei Christopher University: 3453 Mikatahara-cho, Hamamatsu-city, Shizuoka 433-8558, Japan. \\ TEL +81 53-439-1400 FAX +81 53-439-1406 \\ 2) Department of Rehabilitation, Seirei Christopher University
}

Rigakuryoho Kagaku 22(2): 205-208, 2007. Submitted Oct. 16, 2006. Accepted Nov. 21, 2006.

\begin{abstract}
We studied the characteristics of backward walking of elderly people and the relationship between walking and balance ability for the purpose of revealing the characteristics of backward moving of elderly people. The subjects were 11 healthy elderly people participating in a fall prevention class. The measurement items were $10 \mathrm{~m}$ forward walking, $10 \mathrm{~m}$ backward walking, the Functional Reach Test and the one-leg standing test. To examine the difference between forward and backward walking, the t-test was used and the relationship between backward walking and balance ability was analyzed with Pearson's correlation coefficient. The results show that in backward walking of elderly people step width $(p<0.001)$, walking speed $(p<0.001)$ and walking ratio $(p<0.001)$ were reduced compared with forward walking, and that their relationships with balance ability were low. From these results, it became clear that in backward walking of elderly people, walking speed and ratio are reduced by adjustment of step width, suggesting it is possible to evaluate the backward balance shift.
\end{abstract}

Key words: backward walking, balance ability, elderly people

要旨 : 今回，高齢者の後方移動の特徵を明らかにすることを目的に，高齢者の後方歩行の特徵およびバランス能力と の関連性を検討した。対象は転倒予防教室に参加した健常高齢者11名であった。測定項目は, $10 \mathrm{~m}$ 前方歩行，10 m後 方歩行, Functional Reach Test, 片脚立位テストとした。前方歩行と後方歩行との差の検定には, 対応のあるt検定を使 用し，後方歩行とバランス能力との関係をPearsonの相関係数を用いて分析した。結果，高齢者における後方歩行は， 前方歩行に比べて, 歩幅の減少 $(\mathrm{p}<0.001)$, 歩行速度の低下 $(\mathrm{p}<0.001)$, 歩行比の低下 $(\mathrm{p}<0.001)$ が認められ, バ ランス能力との関係は低かった。以上のことから，高齢者の後方歩行は歩幅を減少させることで歩行速度や歩行比を 調整することが明らかとなり，後方へのバランス移動性を捉えることができる可能性が示唆された。

キーワード : 後方歩行, バランス能力, 高齢者

1) 聖隷クリストファー大学リハビリテーション学部理学療法学専攻 学部生 : 静岡県浜松市三方原3453（テ433-8558） TEL 053-439-1400 FAX 053-439-1406

2) 聖隷クリストファー大学リハビリテーション学部理学療法学専攻

受付日 2006年10月16日＼cjkstart受理日２006年11月21日 


\section{I. はじめに}

わが国では, 高齢者の10～30\%が転倒事故を引き起こ しており, そのうちの約1割が骨折などの重篤な障害を 引き起こしている1-3)。また, 転倒や骨折に起因する寝 たきりは，全寝たきり者の $12 \%$ に達していることから， 高齢者の転倒を予防することは重要な課題となってい る。転倒の危険因子は多岐にわたり，これまでに100を 越える危険因子が報告されている4-7)。その中でも, バ ランス機能を含む身体機能の低下は転倒を引き起こす 重要な要因であることが指摘されている8 ${ }^{8,9)}$ 。近年, この ような問題に対してさまざまな測定法が開発され, 各地 で実施されている。しかしながら,これらのほとんどが 前方向に対するバランスの評価であり, 高齢者の生活の 中で困難な動作となっている後方移動を評価するもの は数少ない。高齢者は, 胸腰部後彎や骨盤後傾により, 重心線は後方にシフト寸ることから, 後方への転倒が増 すことが知られている10)。また, 高齢者の後方に対する 転倒は, 大腿骨頚部骨折のリスクがあることも明らかに されており ${ }^{11,12)}$, 後方への移動性を評価することは重要 であると考える。今回, 高齢者の後方歩行の特徵を明ら かにすることを目的に, 歩行評価として広く使用されて いる $10 \mathrm{~m}$ 前方歩行と $10 \mathrm{~m}$ 後方歩行を比較し, 検討した。 また, 後方歩行の後方への移動性を検討するために, バ ランス能力の評価として広く使用され, 静的姿勢保持や 随意運動の要素が高いとされるFunctional Reach Testや片 脚立位との関連性を検討した。

\section{II. 対 象}

転倒予防教室に参加した地域在住高齢者11名（男性3 名, 女性 8 名, 平均年齢76.8 5 5.6歳, 平均身長 $153.0 \pm 8.1$ $\mathrm{cm})$ を対象とした。抽出条件は, 疾患や認知症が影響 しないように，1）前方，後方歩行ともに可能な者，2） 測定者の指示や測定内容について理解可能な者，3）研 究への参加について説明し, 同意が得られた者とした。 また, 安静が保てないなど測定に支障をきたす者は対象 から除外した。

\section{III. 方 法}

1. 歩行評価として, $10 \mathrm{~m}$ 前方歩行, $10 \mathrm{~m}$ 後方歩行を 1 回 ずつ実施し, 歩行に要した時間 (所要時間), 歩数の測 定を行った。なお, 歩行速度はパフォーマンスが最適 化していると言われている ${ }^{13)}$ 自由な速度（自由歩行）
とした。測定は3名の検者で(1)所要時間の測定, (2)歩数 の測定, (3)対象者の介助を分担し, 測定の統一を図っ た。バランス能力の評価として, Functional Reach Test （以下FRT），利き脚による片脚立位時間の測定を行っ た。これらの測定は以下の要領で実施した。

1） $10 \mathrm{~m}$ 前方歩行

$10 \mathrm{~m}$ の直線歩行路（前後3 $\mathrm{m}$ の助走路あり）を自由歩 行で前方に歩き,その所要時間をストップウォッチにて 測定し, 歩数を数えた。

\section{2） $10 \mathrm{~m}$ 後方歩行}

$10 \mathrm{~m}$ の直線歩行路（前後 $3 \mathrm{~m}$ の助走路あり）を自由歩 行で後方に歩き, その所要時間をストップウォッチにて 測定し, 歩数を数えた。

\section{3) Functional Reach Test (FRT)}

あらかじめ壁にメジャーを設定して測定を行った。測 定肢位は両足を肩幅程度に開いた立位とし, 両肩 90 度屈 曲位で両手に棒を握らせた状態から上肢を最大限に前 方に移動させた時の水平移動距離を測定した。測定時, 体幹が前屈し過ぎないように注意し，足部がずれたり， 動いたりしないように指示した。

\section{4）片脚立位時間}

開眼片脚立位時間をストップウォッチにて秒単位で 測定した。測定肢位は，両手に腰を当て，30 cm四方の ビニールテープで囲われた枠内に片脚で立ち, 他方の脚 を床から $5 \mathrm{~cm}$ 程度離した状態とし, バランスを崩した時 点で測定を終了した。なお, 測定值に統一性をもたせる ために測定は利き脚で行った。

\section{2. 歩行パラメーターの算出方法}

測定した所要時間, 歩数, 歩行距離 $(10 \mathrm{~m})$ より, 歩 幅 (歩幅 $(\mathrm{m})=$ 歩行距離 $(\mathrm{m}) /$ 歩数 (steps)) , 歩行率 (歩行率 $(\mathrm{steps} / \mathrm{min})=$ 歩数 $(\mathrm{steps}) /$ 所要時間 $(\mathrm{min}))$, 歩 行速度 (歩行速度 $(\mathrm{m} / \mathrm{min})=$ 歩行距離 $(\mathrm{m})$ /所要時間 $(\mathrm{min}))$, 歩行比 (歩行比 $(\mathrm{m} / \mathrm{steps} / \mathrm{min})=$ 歩幅 $(\mathrm{m}) /$ 歩 行率 $(\mathrm{steps} / \mathrm{min})$ ) を算出した。さらに, 歩幅, 歩行率, 歩行比は身長による影響を受けるため, 身長補正を行っ た。データ処理で使用した歩幅, 歩行率, 歩行比はす心゙ て身長補正したものである。

\section{3. 統計学的解析方法}

前方歩行と後方歩行の歩行パラメーターの差の検定 
には, 対応のあるt検定を用いた。また, 後方歩行で得 られた歩幅, 歩行速度とFRT及び片脚立位時間の相関関 係については, Pearsonの相関係数を用いた。なお, 統計 解析はSPSS 14.0J for Windowsを使用し, 各統計処理にお いて有意水準は5\%未満とした。

\section{IV. 結 果}

1. 前方歩行と後方歩行の歩行パラメーターの比較

前方歩行, 後方歩行における歩幅, 歩行率, 歩行速 度, 歩行比の平均值の差の検定を表 1 に示す。歩幅（前 方歩行 $0.60 \pm 0.08 \mathrm{~m}$, 後方歩行 $0.35 \pm 0.10 \mathrm{~m}: \mathrm{p}<0.001)$, 歩行速度 (前方歩行 $75.1 \pm 9.6 \mathrm{~m} / \mathrm{min}$, 後方歩行 $43.9 \pm 12.1$ $\mathrm{m} / \mathrm{min}: \mathrm{p}<0.001$ ), 歩行比（前方歩行 $0.005 \pm 0.0008 \mathrm{~m} /$ steps $/ \mathrm{min}$, 後方歩行 $0.003 \pm 0.001 \mathrm{~m} / \mathrm{steps} / \mathrm{min}: \mathrm{p}<0.001)$ で，前方歩行と後方歩行の間に有意な差が認められた。 歩行率においては, 前方歩行と後方歩行の間に有意な差 は認められなかった。

\section{2. バランス能力測定結果}

FRT，片脚立位時間の測定結果を表2に示す。対象者 11 名の平均值と標準偏差は, FRTが $28.3 \pm 5.8 \mathrm{~cm}$, 片脚 立位時間は24.9土33.9 secであった。

\section{3. 後方歩行とバランス能力との関係}

後方歩行における歩幅, 歩行速度とFRT, 片脚立位時 間との関係を表3に示す。後方歩行の歩幅及び歩行速度 とFRTとの間に有意な関係は認められなかった（歩幅：

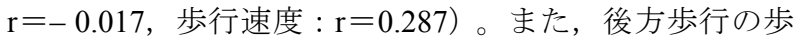
幅及び歩行速度と片脚立位時間との間にも有意な関係 は認められなかった (歩幅: $r=0.260$, 歩行速度 $: r=0.077$ )。

\section{V. 考 察}

本研究では, 高齢者の後方移動の特徵を明らかにす ることを目的に, 高齢者の後方歩行の特徵およびバラン ス能力との関連性を検討した。結果, 高齢者における後 方歩行は, 前方歩行に比べて, 歩幅の減少, 歩行速度の 低下, 歩行比の低下が認められ, バランス能力との関係 も低かった。

歩幅は, 前方歩行で $0.60 \pm 0.08 \mathrm{~m}$, 後方歩行で $0.35 \pm$ $0.10 \mathrm{~m}$ であり，後方歩行で $0.25 \mathrm{~m}$ ほど歩幅が減少した。 後方歩行は, 歩行に必要な主動作筋や力学的要因, 視覚 の情報などあらゆる条件で，前方歩行と異なっている。 例えば, 前方歩行で行う toe offのような力強い推進力を,
表1 前方歩行と後方歩行の比較

\begin{tabular}{lcc}
\hline & 前方歩行 & 後方歩行 $\mathrm{t}$ 検定 \\
\hline 歩幅 $(\mathrm{m})$ & $0.60 \pm 0.08$ & $0.35 \pm 0.10^{*}$ \\
歩行率 $(\mathrm{steps} / \mathrm{min})$ & $126.5 \pm 9.4$ & $129.8 \pm 19.8$ \\
歩行速度 $(\mathrm{m} / \mathrm{min})$ & $75.1 \pm 9.6$ & $43.9 \pm 12.1^{*}$ \\
歩行比 $(\mathrm{m} / \mathrm{steps} / \mathrm{min})$ & $0.005 \pm 0.0008$ & $0.003 \pm 0.001^{*}$ \\
\hline
\end{tabular}

平均士標準偏差, ${ }^{*}: \mathrm{p}<0.001$

表2 バランス能力測定結果

\begin{tabular}{lc}
\hline & 平均值士標準偏差 \\
\hline Functional Reach Test $(\mathrm{cm})$ & $28.3 \pm 5.8$ \\
片脚立位時間 $(\mathrm{sec})$ & $24.9 \pm 33.9$ \\
\hline
\end{tabular}

表3

後方歩行とバランス能力の相関係数

\begin{tabular}{lcc}
\hline & $\begin{array}{c}\text { Functional Reach Test } \\
(\mathrm{cm})\end{array}$ & $\begin{array}{c}\text { 片脚立位時間 } \\
(\mathrm{sec})\end{array}$ \\
\hline 後方歩行の歩幅 $(\mathrm{m})$ & -0.017 & 0.260 \\
後方歩行速度 $(\mathrm{m} / \mathrm{min})$ & 0.287 & 0.077 \\
\hline
\end{tabular}

後方歩行では下腿三頭筋力が十分発揮できないため, 得 ることができない。また, 高齢者の姿勢保持能力は視野 が狭められた条件下で著明に低下寸ることから ${ }^{14)}$, 後方 歩行では進行方向に対する視覚情報が得られず, 高齢者 にとっては非常に困難な歩行状態であったことが考え られる。今回の結果で, 前方歩行に比べ後方歩行の歩幅 に減少が認められた要因には, このような歩行条件の違 いが大きく関与していることが考えられた。歩行速度 は, 前方歩行で75.1 $\pm 9.6 \mathrm{~m} / \mathrm{min}$, 後方歩行で $43.9 \pm 12.1$ $\mathrm{m} / \mathrm{min}$ となり，後方歩行では大きく速度が低下した。金 子は, 歩行速度を低下させる因子として, 歩幅の減少が 強く関与していると報告している15)。我々の結果でも, 前方歩行に比べ，後方歩行の歩幅が大きく変化してお り, 妥当な結果であった。歩行比は, 前方歩行で 0.005 $\pm 0.0008 \mathrm{~m} / \mathrm{steps} / \mathrm{min}$ であり, 後方歩行で $0.003 \pm 0.001 \mathrm{~m} /$ steps/minであり, 標準偏差からみても前方歩行よりも後 方歩行のばらつきが大きく認められた。高歯者は加歯変 化に伴い, 筋力低下や関節可動域の制限, 疼痛などが生 じるため, 歩行パターンに個人差が生じやすい。特に後 方歩行は高齢者にとっては非常に不慣れで困難な歩行 であり, 個人によって制御方法が異なったのであろうと 考える。歩行率は, 前方歩行で $126.5 \pm 9.4 \mathrm{steps} / \mathrm{min}$, 後 方歩行で $129.8 \pm 19.8$ steps/minであり，1分間あたり3歩程 
度の差があったが有意な差は認められなかった。した がって, 歩行速度 (歩幅 $\times$ 歩行率) や歩行比 (歩幅/歩 行率) を低下させた要因は, 歩行率よりも歩幅のほうが 強く関与していたことが考えられた。

後方歩行 (歩幅, 歩行速度) とバランス能力の評価 （FRT，片脚立位時間）との間には有意な関係は認めら れなかった。その要因の一つとして, FRTは重心を前方 一移動させるテストであり, 片脚立位は重心位置を支持 基底面内にとどめておくテストであるが，後方歩行は， 重心を後方へ移動させる動作であるため, これらのバラ ンス能力の評価では後方へのバランス能力を捉えるこ とができなかったことが考えられた。したがって, $10 \mathrm{~m}$ 後方歩行テストは後方へのバランス移動性を示寸指標 になる可能性が示唆された。

本研究の対象者は11名と少なかったが, 前方歩行と後 方歩行の歩行パラメーターの違いが顕著に認められ, 高 齢者の後方歩行の特徴が明らかとなった。また, バラン ス能力の評価として広く使用され, 静的姿勢保持や随意 運動の要素が高いFRTや片脚立位との関係が低かったこ とから, 後方歩行は後方へのバランス移動性を捉えるこ とができる可能性が示唆された。

\section{引用文献}

1) 安村誠司, 芳賀 博, 永井晴美・他 : 地域の在宅高齢者にお ける転倒発生率と転倒状況. 日本公衛誌, 1991, 38(9): 735-741.

2) 新野直明, 安村誠司, 芳賀 博 - 他 : 農村部在宅高齢者を対 象とした転倒調査一季節別にみた転倒者の割合と転倒発生 状況一. 日本公衛誌, 1995, 42(11): 975-981.

3) Luukinen H, Herala M, Koski K, et al.: Fracture risk associated with a fall according to type of fall among the elderly. Osteoporos
Int, 2000, 11(7): 631-634.

4) Lord SR, Clark RD: Physiological and clinical tests for the accurate prediction of falling in older people. J Gerontol, 1996, 42(4): 199-203.

5) Covinsky KE , Kahana E, Kahana B, et al.: History and mobility exam index to identify community-dwelling elderly persons at risk of falling. J Gerontol, 2001, 56(4): 253-259.

6) Wallmann HW: Comparison of elderly nonfallers and fallers on performance measures of functional reach, sensory organization, and limits of stability. J Gerontol, 2001, 56: 580-583.

7) 鈴木隆雄, 杉浦美穂, 古名丈人・他 : 地域高齢者の転倒発生 に関する身体的要因の分析的研究 : 5 年間の追跡研究から. 日老医誌，1999, 36(7): 472-478.

8) 山田和政, 小椋一也, 猪股高志・他 : 身体運動能力における 加齢変化と転倒要因. 芝浦工業大学研究報告, 2003, 37(1): 7985.

9) Haga H, Shibata H, Shichita K, et al.: Fall in the institutionalized elderly in Japan. Arch Gerontol Geriatr, 1986, 5: 1-9.

10) Elble RJ: Change in gait with normal again. In: Gait disorders of aging, 1st ed., Masdeu JC, Alampur U, Cavaliere R, et al. (eds.), Lippincott-Raven, Philadelphia, 1997, pp93-105.

11) Cummings SR, Nevitt MC: A hypothesis:the cause of hip fractures. J Gerontol, 1989, 44(4): 107-111.

12) Norton R, Campbell AJ, Lee-Joe T, et al.: Circumstance of falls resulting in hip fracture among older people. $\mathrm{J}$ Am Geriatr Soc, 1998, 45(9): 1108-1112.

13) Sekiya N, Nagasaki $H$, Ito $H$, et al.: The invariant realationship between step length and step rate during free walking. J Human Movement Studies, 1996, 30: 241-257.

14) Manchester D, Woollacott M, Zederbauer-Hylton N, et al.: Visual, vestibular and somatosensory contribution to balance control in the older adults. J Gerontol, 1989, 44(4): 118-127.

15）金子公宥: 高齢者の歩行運動. J Sports Science, 1991, 10: 729733. 